\title{
Virulence characterization of Campylobacter jejuni isolated from resident wild birds in Tokachi area, Japan
}

\author{
Anselme SHYAKA ${ }^{1,2}$, Akiko KUSUMOTO ${ }^{1}$, Warangkhana CHAISOWWONG ${ }^{1,3)}$, Yoshiki OKOUCHI ${ }^{1)}$, \\ Shinya FUKUMOTO ${ }^{4)}$, Aya YOSHIMURA ${ }^{4)}$ and Keiko KAWAMOTO ${ }^{1) *}$ \\ ${ }^{1)}$ Section of Food Microbiology and Immunology, Diagnostic Center for Animal Health and Food Safety, Obihiro University of \\ Agriculture and Veterinary Medicine, 2-11 Inada, Obihiro, Hokkaido 080-8555, Japan \\ 2) University of Rwanda, the College of Agriculture and Veterinary Medicine, P.O. Box 210 Musanze, Rwanda \\ ${ }^{3}$ Department of Veterinary Biosciences and Veterinary Public Health, Faculty of Veterinary Medicine, Chiang Mai University, Mae Hia, \\ Muang, Chiang Mai 50100, Thailand \\ 4) Research Unit for Vector Biology, National Research Center for Protozoan Diseases, Obihiro University of Agriculture and Veterinary \\ Medicine, 2-11 Inada, Obihiro, Hokkaido 080-8555, Japan
}

(Received 13 February 2015/Accepted 20 March 2015/Published online in J-STAGE 4 April 2015)

ABSTRACT. The prevalence of Campylobacter jejuni in wild birds is a potential hazard for human and animal health. The aim of this study was to establish the prevalence of $C$. jejuni in wild birds in Tokachi area, Hokkaido, Japan and investigate their virulence in vitro. In total, 173 cloacal swabs from individual wild birds were collected for the detection of Campylobacter spp. Thirty four samples (19.7\%) were positive for Campylobacter of which $94.1 \%$ (32/34 samples) were C. jejuni. Additionally, one C. coli and one C. fetus were isolated. Seven $C$. jejuni isolates (one from crows and the other from pigeons) had important virulence genes including all three CDT genes ( $c d t A, c d t B$ and $c d t C$ ) and $f l a A, f l a B, c i a B$ and $c a d F$, and the other isolates were lacking $c d t A$ gene. Further studies on in vitro virulence-associated phenotypes, such as motility assay on soft agar and invasion assay in Caco-2 cells, were performed. The wild bird $C$. jejuni isolates adhered and invaded human cells. Although the numbers of viable intracellular bacteria of wild bird isolates were lower than a type strain NCTC11168, they persisted at 48 -hr and underwent replication in host cells.

KEY WORDS: Campylobacter, Japan, virulence, wild bird

doi: 10.1292/jvms.15-0090; J. Vet. Med. Sci. 77(8): 967-972, 2015

The genus Campylobacter is microaerophilic, spiralshaped, motile Gram-negative bacilli with unipolar or bipolar flagella [33]. It is widely distributed in multiple animal hosts including livestock, wild and companion animals, and also, it is found from environmental sources [8, 22]. Among 17 species of the genus, C. jejuni is the leading cause of human bacterial gastroenteritis in developed countries and accounts for $\sim 90 \%$ of cases of campylobacteriosis [40]. Patients present with watery and bloody diarrhea accompanied by fever and abdominal pain after a latency period of 2 to 5 days, as well as headaches and nausea [7]. Campylobacter infection has also been suggested to be associated with acute polyradiculitis (Guillain-Barré syndrome) [3, 29].

In US, 13,000 hospitalizations attributed to $C$. jejuni including 100 deaths are reported each year [36]. On the other hand, 34 cases per 100,000 inhabitants and 300 cases per 100,000 inhabitants were reported annually in Canada (http://dsol-smed.phac-aspc.gc.ca/dsol-smed/ndis/charts.

\footnotetext{
*Correspondence to: Kawamoto, K., Section of Food Microbiology and Immunology, Diagnostic Center for Animal Health and Food Safety, Obihiro University of Agriculture and Veterinary Medicine, 2-11 Inada, Obihiro, Hokkaido 080-8555, Japan. e-mail: kkeiko@obihiro.ac.jp

(C)2015 The Japanese Society of Veterinary Science

This is an open-access article distributed under the terms of the Creative Commons Attribution Non-Commercial No Derivatives (by-nc-nd) License $<$ http://creativecommons.org/licenses/by-nc-nd/3.0/>.
}

php?c=pl) and New Zealand [4], respectively. In Japan, C. jejuni is also recognized as the prominent foodborne bacterium since 1998, and it has accounted for 300 to 600 cases each year according to the statistical data from Ministry of Health, Labour and Welfare (http://idsc.nih.go.jp/ iasr/31/359/tpc359.html).

Humans are infected mainly through consumption of contaminated raw or undercooked food and drinking water $[2,10]$. Other potential routes of infection have been documented, such as contact with reservoir animals including farm and companion animals, and environmental exposures including wild birds [16], since this pathogen has the ability to colonize a range of environmental reservoirs and multiple animal hosts [31].

C. jejuni is considered to be a commensal bacterium in poultry where its infection is high, with a rate ranging from 50 to $80 \%[5,35]$. Bird intestines provide optimal conditions for the growth of thermophilic Campylobacter, allowing these avian species to serve as asymptomatic carriers $[3,5$, 9].

Wild birds are also hosts to Campylobacter species, and because of their mobility, they may cause widespread contamination. Campylobacter has been isolated from birds, such as crows and pigeons, sharing the same living area and habitat with humans $[12,17,19,21,26,38]$. Certain cases of contaminated food and drinking water have also been caused by transmission via wild birds $[1,3,38]$. These reports suggest that wild birds may have an impact on Campylobacter 
infection in humans. Further, scavenging birds, such as sea gulls and crows, hunting for food in areas with raw garbage, are of concern as they may disseminate the bacteria to humans and livestock through contact or environmental contamination.

Previous studies in Japan have reported the occurrence of $C$. jejuni in wild birds [12, 17, 21, 25-27]. However, the potential virulence of wild bird isolates to humans has not been investigated. In this study, we isolated Campylobacter from resident wild birds and examined their virulence characteristics to evaluate the potential health risk to humans and animals.

\section{MATERIALS AND METHODS}

Sample collection: A total of 173 cloacal swab samples were collected from individual dead birds including 139 crows (Corvus corone and C. macrorhynchos), 24 pigeons (Columbia livia and Streptopelia orientalis) and 10 Eurasian tree sparrows (Passer montanus). Wild birds were captured by a bird trap for pest control in Tokachi area, Hokkaido, Japan during May 2010 to May 2011. The birds were sacrificed with gas euthanasia. We also collected samples from officially-sanctioned hunted birds during the above period. Birds were taken to the laboratory, and cloacal feces were immediately transferred to commercial transport medium (Eiken Chemical, Tochigi, Japan) with sterile cotton-tipped swabs. Samples were kept at cool temperature and processed for the microbiological isolation within one day after sampling.

Isolation and identification of Campylobacter isolates: One $\mathrm{m} l$ portion of transport medium was transferred to 9 $\mathrm{m} l$ of Bolton broth (Oxoid, Hampshire, U.K.). The broth culture was incubated at $42^{\circ} \mathrm{C}$ under microaerobic condition (AnaeroPack-MicroAero, Mitsubishi Gas Chemical, Tokyo, Japan) for $48 \mathrm{hr}$, and subsequently, a loopful of culture was streaked on modified Charcoal Cefoperazone Deoxycholate Agar (mCCDA) plate (Oxoid). The plates were incubated at the same condition for $48 \mathrm{hr}$. Suspected colonies were subjected to Gram-staining, oxidase test, catalase test and Dryspot Campylobacter test (Oxoid). All Campylobacter isolates were subjected to $16 \mathrm{~S}$ rDNA sequencing for inter species identification [38]. The reactions were performed using SYBR Premix Ex Taq Kit (Takara Bio, Otsu, Japan), and amplification was carried out in a LightCycler 480 (Roche Diagnostics, Rotkreuz, Switzerland).

Detection of virulence genes: DNA extraction from $C$. jejuni isolates was performed using PrepMan Ultra Sample Preparation Reagent (Life Technologies Japan, Tokyo, Japan) according to the manufacturer's instruction. Realtime PCR was used to examine the presence of following virulence-associated genes in: $f l a A, f l a B, c i a B, c a d F, c d t A$, $c d t B$ and $c d t C$. The amplification was performed as described previously [11]. The size of the obtained amplicon was verified using a $2 \%$ gel electrophoresis and visualized with UV trans-illumination after ethidium bromide staining.

Bacterial motility: Swarming motility of C. jejuni isolates was investigated according to the method described by Scott et al. [34]. Briefly, two microliters of grown bacteria were inoculated onto Mueller Hinton II broth (BD, Franklin Lakes, NJ, U.S.A.) with $0.4 \%$ agar. The diameter of the resulting swarming colonies was measured following incubation for $23 \mathrm{hr}$ at $42^{\circ} \mathrm{C}$ in microaerobic conditions. C. jejuni strain NCTC11168, which was a clinical isolate and widely used, was used as a control [18].

Gentamicin protection assay: Invasive abilities of $C$. jejuni isolates to human colonic epithelial cell line Caco-2 cells were examined by gentamicin protection assay with slight modifications [14]. Caco-2 cells was maintained in Eagle's Minimum Essential Medium (E-MEM; Sigma, St. Louis, MO, U.S.A.) supplemented with $10 \%$ fetal bovine serum (FBS) (Invitrogen, Carlsbad, CA, U.S.A.), penicillinstreptomycin, $100 \mathrm{mM}$ L-glutamine, $100 \mathrm{mM}$ sodium pyruvate and E-MEM amino acid (Sigma) at $37^{\circ} \mathrm{C}$ with $5 \%$ $\mathrm{CO}_{2}$. The monolayer of Caco- 2 cells $\left(1.0 \times 10^{5}\right.$ cells/well $)$ in a 24-well culture plate was infected with $C$. jejuni at MOI of 50, and the culture plates were centrifuged at 3,000 rpm for $5 \mathrm{~min}$ to allow inoculated bacteria to adhere on Caco-2 cell surface. After $1 \mathrm{hr}$, non-adherent bacteria were removed by washing with $9.6 \mathrm{mM}$ phosphate buffered saline (PBS), $\mathrm{pH}$ 7.4. The extracellular bacteria were killed by gentamicin $(100 \mu \mathrm{g} / \mathrm{ml})$ for $2 \mathrm{hr}$ at $37^{\circ} \mathrm{C}$. After washing, the medium was replaced with E-MEM with $10 \% \mathrm{FBS}$, and then, the Caco-2 cells were lysed by $500 \mu l$ of $0.1 \%$ Triton X- 100 (Wako Pure Chemical, Osaka, Japan) in PBS at 1-hr, 24-hr and 48-hr post infection. The intracellular culturable bacteria were counted on mCDDA medium.

Statistical analysis: The significance of differences between the groups was evaluated by one-way analysis of variance (ANOVA). Statistical analysis was performed with Graph Pad Prism software version 5 (Graph Pad Software Inc., La Jolla, CA, U.S.A.). The $P$-values $<0.05$ were considered significant.

\section{RESULTS}

Prevalence of Campylobacter spp. in wild birds in Obihiro: A total of $19.7 \%$ (34/173) samples from wild-living birds, including $20.9 \%$ (27/139) from the crows, $25 \%(6 / 24)$ from the pigeons and $10 \%(1 / 10)$ from the sparrows, were positive for Campylobacter spp. (Table 1). Of the 27 croworiginated isolates of Campylobacter spp., 25 (92.6\%) were identified as C. jejuni, $1(3.7 \%)$ as $C$. coli and $1(3.7 \%)$ as C. fetus. Six samples from pigeons and one sample isolated from Eurasian tree sparrows, all Campylobacter-positive, were all confirmed as $C$. jejuni.

Detection of virulence genes using real-time PCR: Thirtythree isolates of $C$. jejuni from wild birds were screened for the presence of virulence genes. Real-time PCR was used to seven important $C$. jejuni virulence-related genes namely $c d t A, c d t B$ and $c d t C$, genes related with the cytotoxin expression, $f l a A, f l a B$ and $c a d F$, linked with adherence and colonization; and $c i a B$, associated with invasion (Table 2). Seven C. jejuni isolates (six isolated from pigeons and one from a crow) harbored all the 7 virulence genes investigated. Other remaining 25 isolates ( 24 from crows and 1 from a Eurasian 
Table 1. Prevalence of C. jejuni in wild birds in Obihiro

\begin{tabular}{|c|c|c|c|c|}
\hline Birds & $\begin{array}{l}\text { Total no. of } \\
\text { samples }\end{array}$ & $\begin{array}{c}\text { No. of samples positive for } \\
\text { Campylobacter spp. (\%) }\end{array}$ & \multicolumn{2}{|c|}{$\begin{array}{l}\text { Isolated species and } \\
\text { proportion }(\%)\end{array}$} \\
\hline Crow (Corvus corone and C. macrorhynchos) & 139 & $27(20.9)$ & $\begin{array}{l}\text { C. jejuni } \\
\text { C. coli } \\
\text { C. fetus }\end{array}$ & $\begin{array}{c}25(92.6) \\
1(3.7) \\
1(3.7)\end{array}$ \\
\hline Pigeon (Columba livia and Streptopelia orientalis) & 24 & $6(25.0)$ & C. jejuni & $6(100.0)$ \\
\hline Eurasian tree sparrow (Passer montanus) & 10 & $1(10.0)$ & C. jejuni & $1(100.0)$ \\
\hline Total & 173 & $34(19.7)$ & $\begin{array}{l}\text { C. jejuni } \\
\text { C. coli } \\
\text { C. fetus }\end{array}$ & $\begin{array}{r}32(15.5) \\
1(10.6) \\
1(10.6)\end{array}$ \\
\hline
\end{tabular}

tree sparrow) were positive for $c d t B, c d t C, f l a A, f l a B, c a d F$ and $c i a B$, but $c d t A$ gene (Table 2).

Motility assay on soft-agar plate: Since 7 isolates (C38, P3, P5, P6, P8, P9 and P10) were found to be positive for the 7 virulence genes, flagella-mediated motility of them was studied using a standard soft-agar assay. One isolate (C38, from crow sample) showed a high motility after 23-hr incubation, whereas no motility was observed in other isolates (Fig. 1).

Invasiveness and proliferation of $C$. jejuni isolates from wild birds: To understand the $C$. jejuni isolates invasion and proliferation ability in an epithelial cell-line, 7 isolates harboring all 7 virulence-associated genes (C38, P3, P5, P6, P8, $\mathrm{P} 9$ and $\mathrm{P} 10)$ and 2 isolates lacking $c d t A$ gene $(\mathrm{C} 1$ and $\mathrm{C} 2)$ were used in the human intestinal Caco-2 cell-line invasion assay. As observed 1-hr post-infection (Fig. 2), isolates from wild birds showed a high ability to invade Caco-2 cells at a comparable level as with NCTC11168. All isolates tested adhered and invaded into Caco-2 cells, and persisted within the cells for $48 \mathrm{hr}$. No significant difference was observed between the isolates. After $24 \mathrm{hr}$, all the tested isolates showed 1.2 log-reduction in the internal bacteria number
Table 2. Real-time PCR results of virulence-related genes in $C$. jejuni isolated from wild birds

\begin{tabular}{lccccccc}
\hline \multicolumn{1}{c}{ Birds (no. of samples) } & $c d t A$ & $c d t B$ & $c d t C$ & flaA & flaB & ciaB & cadF \\
\hline Crow (24) & - & + & + & + & + & + & + \\
Crow (1) & + & + & + & + & + & + & + \\
Pigeon (6) & + & + & + & + & + & + & + \\
Eurasian tree sparrow (1) & - & + & + & + & + & + & + \\
\hline
\end{tabular}

counts. At $48 \mathrm{hr}$, isolates from wild birds showed a slight increase (average, $0.2 \mathrm{Log}$ ) and underwent replication. The number of bacteria of wild bird isolates at $24 \mathrm{hr}$ and $48 \mathrm{hr}$ was significantly lower than those of NCTC11168 (Fig. 2).

\section{DISCUSSION}

The present study yielded the following new findings. First, our study is the first report of Campylobacter spp. prevalence in resident wild birds of Hokkaido area. Second, we examined virulence-associated activities of wild bird C. jejuni isolates in comparison with those of type strain
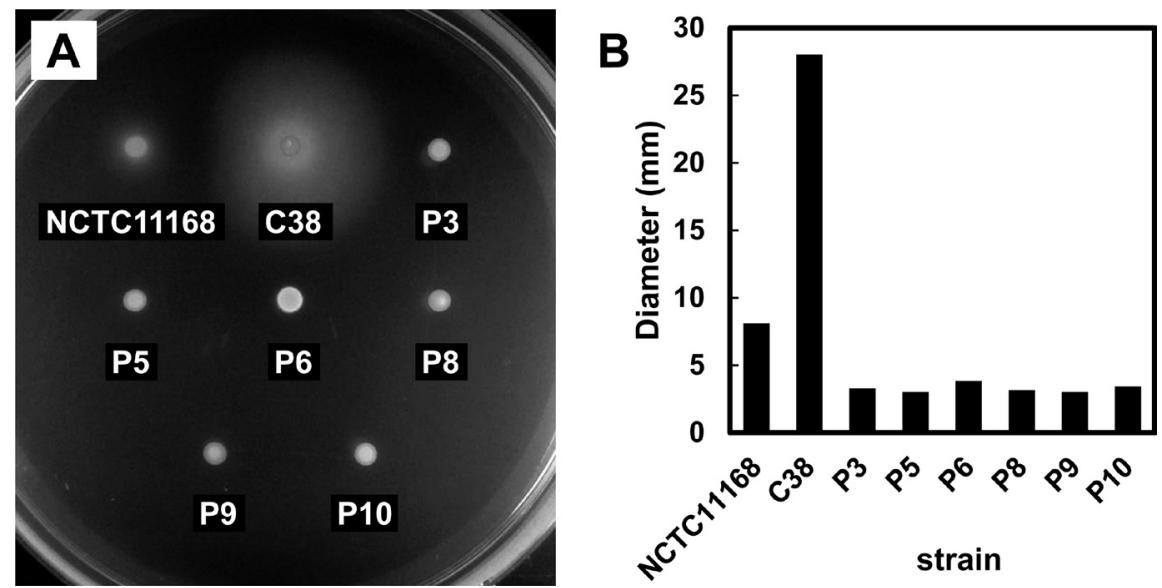

Fig. 1. Motility of C. jejuni isolates (C38, P3, P5, P6, P8, P9 and P10) on soft agar plate. (A) Photograph of swarming colonies of $C$. jejuni strains on $0.4 \%$-agar Mueller Hinton II plate after 23 -hr incubation. (B) Diameter of swarming colonies of the C. jejuni isolates after 23-hr incubation. The clinical isolate NCTC11168 was used as a control. 


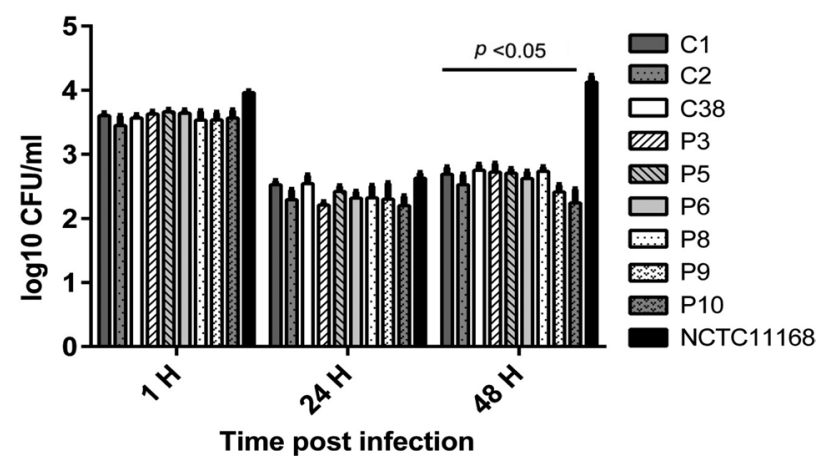

Fig. 2. Gentamicin protection assay in Caco-2 cells. Caco-2 cells were incubated with $C$. jejuni as described in Materials and Methods. After for 1-, 24- or 48-hr incubation, bacterial cells in Caco-2 cells were counted on mCDDA. Experiment was done in triplicate. NCTC11168 was used as a control. Significant difference of the wild-bird isolates to NCTC11168 at 48-hr incubation: $P<0.05$.

NCTC11168. To our knowledge, no reports are available that demonstrate virulence properties of $C$. jejuni isolates from wild birds.

Overall prevalence of Campylobacter spp. in wild birds in this study was $19.7 \%$. The prevalence of Campylobacter in this study showed average level when compared with the results from other studies, which described Campylobacter spp. in wild birds in the range of 3-80\% around the world [1]. The species identification showed that most isolates were $C$. jejuni in our study as the same with other domestic and overseas studies, although $C$. coli and C. fetus were found in one sample each. C. jejuni and C. coli account for $95 \%$ of campylobacteriosis in humans, while $C$. fetus is of veterinary importance due to its ability to colonize the intestinal mucosa and/or urogenital tract in cattle, causing abortion and sterility. C. fetus can also infect humans, especially elderly and immunocompromized individuals [20, 37].

The isolation rates reported in previous Japanese studies on $C$. jejuni carriage in wild birds are variable. Kinjo et al. [25] found that $23.7 \%$ of tested pigeons $(n=329)$ were infected by $C$. jejuni on a two-year survey. Fukuyama et al. [17] have reported a lower overall rate than ours. In fact, $7.9 \%(n=700)$ in all sampled birds and $13.5 \%(n=378)$ in pigeons were observed. Ito et al. [21] have described an overall rate of $14 \%(n=313)$, but a higher infection rate in crows, $34 \%(n=32)$ possibly due to their association with a municipal garbage dump. The infection rate varied between these studies and ours, possibly due to different sample sizes, sampling methods and investigated localities. Higher percentage of infection was found in crows and pigeons than in the Eurasian tree sparrows. The occurrence of $C$. jejuni in various wild bird species might have a link with their diet. In fact, the main food sources for sparrow are seed, grain and insects, while the scavenging birds, such as crows and pigeons, are known to feed in garbage [21]. The relationship between Campylobacter infection and wild birds diet seems to be further confirmed by results reported by Ito et al. [21] and Kapperud and Rosef [23]. They found that herbivorous wild birds were also infected, but at a significantly lower rate than other omnivorous scavenger, such as crows and gulls. These factors made the crows and pigeons to be more exposed to isolates from food animals and humans as their habitats are closely shared.

To gain insight to the pathogenicity of $C$. jejuni isolates from wild birds, we characterized the isolates for the presence of major virulence-associated genes, such as $c a d F$, $c d t A, c d t B, c d t C, c i a B, f l a A$ and $f l a B$. The virulence genes screened to assess the pathogenesis of $C$. jejuni have been reviewed by Dasti et al. [13] and Young et al. [41]. The gene $c a d F$ encodes an outer membrane protein that interacts with host cells to bind to the extracellular matrix protein fibronectin and thus is important for colonization. The cytolethal distending toxin (CDT) is encoded by $c d t A, c d t B$ and $c d t C$, and their expression is required for their cytotoxicity effect [32]. The tripartite CDT complex triggers the arrest of eukaryotic cells in the G2 phase of the cell cycle causing apoptosis of the concerned cell [39]. The flagellin proteins encoded by $f l a A$ and $f l a B$ have been recognized as important factors in C. jejuni motility and invasion [30, 33]. Thirty-two isolates of $C$. jejuni from wild birds were screened for the presence of virulence genes, and seven $C$. jejuni isolates ( 1 crow isolate and all 6 isolates from pigeons) were positive for all tested genes. The other 25 isolates were lacking $c d t A$ in the virulence gene profile. This might be due to the complete absence of $c d t A$ or occurrence of mutations in respective gene.

Motility is critical for many of $C$. jejuni pathogenesis properties, such as host colonization, secretion of virulence genes and host-cell invasion [41]. C. jejuni isolates from wild birds showed a reduced motility with exception of $\mathrm{C} 38$, which showed a high motility phenotype (Fig. 1A and 1B). On the other hand, PCR results confirmed the presence, in all isolates from wild birds, of $f l a A$ and $f l a B$, the two major flagellin genes of $C$. jejuni. These results suggest that the defects in swarming motility are caused by lack or loss-offunction of other flagellar genes, or lack of chemotactic ability. It has been postulated that naturally, C. jejuni can produce non-motile deletion copies of wild type strain that are more suitable to environments where the flagellar expression would be unnecessary otherwise [24]. These phenotypes may restore their motility, once favorable conditions are met.

Another objective of our study was to determine the invasive capabilities of $C$. jejuni isolates from wild birds to the human intestinal epithelial cell-line, Caco-2. At 1-hr post-infection, intracellular $C$. jejuni of tested isolates was comparable, followed by an identical decrease at $24-\mathrm{hr}$ post infection for all isolates including the clinical isolate. However, at 48-hr post infection, isolates from wild birds showed a similar slight increase (i.e. multiplication inside Caco-2 cells), except for the clinical isolate that showed a sharp significantly different increase. It has been reported that clinical isolates are hyper invasive compared to isolates from asymptomatic individuals $[6,15]$. It also has been hypothesized that the virulent capacity of $C$. jejuni is attenuated by the lysosome system which prevents the bacteria to survive nor multiply inside cultured cells [28]. The tested isolates of C. jejuni from wild birds were invasive phenotype. Although 
weaker, the invasion of Caco-2 cells by the isolates of this study was observed and this highlights their potential as human pathogens.

To our knowledge, this study is the first study to investigate virulence-associated factors of $C$. jejuni isolates from wild birds. While the type strain NCTC11168 was greater in adherence and invasion capacities to Caco- 2 cells than those of wild bird isolates, they invaded the human intestinal epithelial cells, persisted and underwent replication in host cells. Since little is known about the link between wild bird origin of Campylobacter and human and livestockassociated strains, further studies, such as hemolysis and cytotoxicity assay, in vivo infection studies and molecular epidemiological studies, need to be performed to elucidate the pathogenicity of wild bird isolates and their impact on human and animal health.

ACKNOWLEDGMENTS. This work was funded by a grant from Ministry of Education, Culture, Sports, Science and Technology (MEXT), by a Grant-in-Aid for Scientific Research from the Japanese Society for the Promotion of Science and by a grant from the Ministry of Health, Labor and Welfare. We are grateful to the Obihiro section, Hokkaido branch of the Japan Hunting Association for sampling wild birds. We would like to thank Ms. Masumi Kagawa, Ms. Mio Yagihashi for their technical assistance. We are thankful to the National BioResource Project for providing Caco-2 cell.

\section{REFERENCES}

1. Abulreesh, H. H., Goulder, R. and Scott, G. W. 2007. Wild birds and human pathogens in the context of ringing and migration. Ringing Migr. 23: 193-200. [CrossRef]

2. Allos, B. M. 2001. Campylobacter jejuni Infections: update on emerging issues and trends. Clin. Infect. Dis. 32: 1201-1206. [Medline] [CrossRef]

3. Altekruse, S. F., Stern, N. J., Fields, P. I. and Swerdlow, D. L. 1999. Campylobacter jejuni-an emerging foodborne pathogen. Emerg. Infect. Dis. 5: 28-35. [Medline] [CrossRef]

4. Baker, M. G., Sneyd, E. and Wilson, N. A. 2007. Is the major increase in notified campylobacteriosis in New Zealand real? Epidemiol. Infect. 135: 163-170. [Medline] [CrossRef]

5. Beery, J. T., Hugdahl, M. B. and Doyle, M. P. 1988. Colonization of gastrointestinal tracts of chicks by Campylobacter jejuni. Appl. Environ. Microbiol. 54: 2365-2370. [Medline]

6. Biswas, D., Itoh, K. and Sasakawa, C. 2000. Uptake pathways of clinical and healthy animal isolates of Campylobacter jejuni into INT-407 cells. FEMS Immunol. Med. Microbiol. 29: 203-211. [Medline] [CrossRef]

7. Black, R. E., Levine, M. M., Clements, M. L., Hughes, T. P. and Blaser, M. J. 1988. Experimental Campylobacter jejuni infection in humans. J. Infect. Dis. 157: 472-479. [Medline] [CrossRef]

8. Bolton, F. J., Surman, S. B., Martin, K., Wareing, D. R. and Humphrey, T. J. 1999. Presence of Campylobacter and Salmonella in sand from bathing beaches. Epidemiol. Infect. 122: 7-13. [Medline] [CrossRef]

9. Broman, T., Palmgren, H., Bergström, S., Sellin, M., Waldenström, J., Danielsson-Tham, M. L. and Olsen, B. 2002. Campylobacter jejuni in black-headed gulls (Larus ridibundus): prevalence, genotypes, and influence on C. jejuni epidemiology.
J. Clin. Microbiol. 40: 4594-4602. [Medline] [CrossRef]

10. Butzler, J. P. 2004. Campylobacter, from obscurity to celebrity. Clin. Microbiol. Infect. 10: 868-876. [Medline] [CrossRef]

11. Chaisowwong, W., Kusumoto, A., Hashimoto, M., Harada, T., Maklon, K. and Kawamoto, K. 2012. Physiological characterization of Campylobacter jejuni under cold stresses conditions: its potential for public threat. J. Vet. Med. Sci. 74: 43-50. [Medline] [CrossRef]

12. Chuma, T., Hashimoto, S. and Okamoto, K. 2000. Detection of thermophilic Campylobacter from sparrows by multiplex PCR: the role of sparrows as a source of contamination of broilers with Campylobacter. J. Vet. Med. Sci. 62: 1291-1295. [Medline] [CrossRef]

13. Dasti, J. I., Tareen, A. M., Lugert, R., Zautner, A. E. and Gross, U. 2010. Campylobacter jejuni: a brief overview on pathogenicity-associated factors and disease-mediating mechanisms. Int. J. Med. Microbiol. 300: 205-211. [Medline] [CrossRef]

14. Elsinghorst, E. A. 1994. Measurement of invasion by gentamicin resistance. Methods Enzymol. 236: 405-420. [Medline] [CrossRef]

15. Fearnley, C., Manning, G., Bagnall, M., Javed, M. A., Wassenaar, T. M. and Newell, D. G. 2008. Identification of hyperinvasive Campylobacter jejuni strains isolated from poultry and human clinical sources. J. Med. Microbiol. 57: 570-580. [Medline] [CrossRef]

16. French, N. P., Midwinter, A., Holland, B., Collins-Emerson, J., Pattison, R., Colles, F. and Carter, P. 2009. Molecular epidemiology of Campylobacter jejuni isolates from wild-bird fecal material in children's playgrounds. Appl. Environ. Microbiol. 75: 779-783. [Medline] [CrossRef]

17. Fukuyama, M., Kamimura, T., Itoh, T., Saito, K., Takahashi, M., Sakai, S., Murata, M., Kohzaki, K., Hara, M., Shimizu, T. and Tabuchi, K. 1986. Distribution of Campylobacter jejuni in wild birds and serogroup of isolates by slide agglutination technique. Nippon Juigaku Zasshi 48: 487-493. [Medline] [CrossRef]

18. Gaynor, E. C., Cawthraw, S., Manning, G., MacKichan, J. K., Falkow, S. and Newell, D. G. 2004. The genome-sequenced variant of Campylobacter jejuni NCTC 11168 and the original clonal clinical isolate differ markedly in colonization, gene expression, and virulence-associated phenotypes. J. Bacteriol. 186: 503-517. [Medline] [CrossRef]

19. Hughes, L. A., Bennett, M., Coffey, P., Elliott, J., Jones, T. R., Jones, R. C., Lahuerta-Marin, A., Leatherbarrow, A. H., McNiffe, K., Norman, D., Williams, N. J. and Chantrey, J. 2009. Molecular epidemiology and characterization of Campylobacter spp. isolated from wild bird populations in northern England. Appl. Environ. Microbiol. 75: 3007-3015. [Medline] [CrossRef]

20. Ichiyama, S., Hirai, S., Minami, T., Nishiyama, Y., Shimizu, S., Shimokata, K. and Ohta, M. 1998. Campylobacter fetus subspecies fetus cellulitis associated with bacteremia in debilitated hosts. Clin. Infect. Dis. 27: 252-255. [Medline] [CrossRef]

21. Ito, K., Kubokura, Y., Kaneko, K., Totake, Y. and Ogawa, M. 1988. Occurrence of Campylobacter jejuni in free-living wild birds from Japan. J. Wildl. Dis. 24: 467-470. [Medline] [CrossRef]

22. Jones, K. 2001. Campylobacters in water, sewage and the environment. Symp. Ser. Soc. Appl. Microbiol. 90: 68S-79S. [Medline] [CrossRef]

23. Kapperud, G. and Rosef, O. 1983. Avian wildlife reservoir of Campylobacter fetus subsp. jejuni, Yersinia spp., and Salmonella spp. in Norway. Appl. Environ. Microbiol. 45: 375-380. [Medline]

24. Karlyshev, A. V., Linton, D., Gregson, N. A. and Wren, B. W. 
2002. A novel paralogous gene family involved in phase-variable flagella-mediated motility in Campylobacter jejuni. Microbiology 148: 473-480. [Medline]

25. Kinjo, T., Morishige, M., Minamoto, N. and Fukushi, H. 1983. Prevalence of Campylobacter jejuni in feral pigeons. Nippon Juigaku Zasshi 45: 833-835. [Medline] [CrossRef]

26. Maruyama, S., Tanaka, T., Katsube, Y., Nakanishi, H. and Nukina, M. 1990. Prevalence of thermophilic campylobacters in crows (Corvus levaillantii, Corvus corone) and serogroups of the isolates. Nippon Juigaku Zasshi 52: 1237-1244. [Medline] [CrossRef]

27. Matsusaki, S., Katayama, A., Itagaki, K., Yamagata, H., Tanaka, K., Yamami, T. and Uchida, W. 1986. Prevalence of Campylobacter jejuni and Campylobacter coli among wild and domestic animals in Yamaguchi Prefecture. Microbiol. Immunol. 30: 1317-1322. [Medline] [CrossRef]

28. De Melo, M. A., Gabbiani, G. and Pechère, J. C. 1989. Cellular events and intracellular survival of Campylobacter jejuni during infection of HEp-2 cells. Infect. Immun. 57: 2214-2222. [Medline]

29. Mishu, B. and Blaser, M. J. 1993. Role of infection due to Campylobacter jejuni in the initiation of Guillain-Barré syndrome. Clin. Infect. Dis. 17: 104-108. [Medline] [CrossRef]

30. Morooka, T., Umeda, A. and Amako, K. 1985. Motility as an intestinal colonization factor for Campylobacter jejuni. J. Gen. Microbiol. 131: 1973-1980. [Medlin]

31. Newell, D. G. 2002. The ecology of Campylobacter jejuni in avian and human hosts and in the environment. Int. J. Infect. Dis. 6 Suppl 3: S16-S20, discussion S20-S21, S53-S58. [Medline] [CrossRef]

32. Pickett, C. L. and Whitehouse, C. A. 1999. The cytolethal distending toxin family. Trends Microbiol. 7: 292-297. [Medline] [CrossRef]

33. Poly, F., Ewing, C., Goon, S., Hickey, T. E., Rockabrand, D.,
Majam, G., Lee, L., Phan, J., Savarino, N. J. and Guerry, P. 2007. Heterogeneity of a Campylobacter jejuni protein that is secreted through the flagellar filament. Infect. Immun. 75: 3859-3867. [Medline] [CrossRef]

34. Scott, A. E., Timms, A. R., Connerton, P. L., Loc Carrillo, C., Adzfa Radzum, K. and Connerton, I. F. 2007. Genome dynamics of Campylobacter jejuni in response to bacteriophage predation. PLoS Pathog. 3: e119. [Medline] [CrossRef]

35. Shane, S. M. 1992. The significance of Campylobacter jejuni infection in poultry: a review. Avian Pathol. 21: 189-213. [Medline] [CrossRef]

36. Silva, J., Leite, D., Fernandes, M., Mena, C., Gibbs, P. A. and Teixeira, P. 2011. Campylobacter spp. as a Foodborne Pathogen: A Review. Front Microbiol 2: 200. [Medline] [CrossRef]

37. Sprenger, H., Zechner, E. L. and Gorkiewicz, G. 2012. So close and yet so far - Molecular Microbiology of Campylobacter fetus subspecies. Eur. J. Microbiol. Immunol. (Bp) 2: 66-75. [Medline] [CrossRef]

38. Weis, A. M., Miller, W. A., Byrne, B. A., Chouicha, N., Boyce, W. M. and Townsend, A. K. 2014. Prevalence and pathogenic potential of campylobacter isolates from free-living, humancommensal american crows. Appl. Environ. Microbiol. 80: 1639-1644. [Medline] [CrossRef]

39. Whitehouse, C. A., Balbo, P. B., Pesci, E. C., Cottle, D. L., Mirabito, P. M. and Pickett, C. L. 1998. Campylobacter jejuni cytolethal distending toxin causes a G2-phase cell cycle block. Infect. Immun. 66: 1934-1940. [Medline]

40. Wieczorek, K. 2010. Antimicrobial resistance and virulence markers of Campylobacter jejuni and Campylobacter coli isolated from retail poultry meat in Poland. Bull. Vet. Inst. Puławy 54: 563-569.

41. Young, K. T., Davis, L. M. and Dirita, V. J. 2007. Campylobacter jejuni: molecular biology and pathogenesis. Nat. Rev. Microbiol. 5: 665-679. [Medline] [CrossRef] 